CARVALHO, ADF; MADEIRA, NR; SILVA, GO. 2018. Adaptability and stability of commercial yield of arracacha in southern region of Minas Gerais State. Horticultura Brasileira 36: 100-105. DOI - http://dx.doi.org/10.1590/S0102-053620180117

\title{
Adaptability and stability of commercial yield of arracacha in southern region of Minas Gerais State
}

\author{
Agnaldo DF Carvalho; Nuno R Madeira; Giovani O Silva
}

Embrapa Hortaliças, Brasília-DF, Brazil; agnaldo.carvalho@embrapa.br; nuno.madeira@embrapa.br (corresponding author); giovani. olegario@embrapa.br

\begin{abstract}
The arracacha is a great economical alternative for Brazilian farmers. The aim of this research was to determine the stability and adaptability of arracacha clones by the methodology of factors analysis and bissegmented regression. Five clones, three cultivars (Amarela de Senador Amaral, BRS Rubia 41 and BRS Catarina 64), and two advanced clones (EH-48 and EH-56) were evaluated in 10 locations in the southern of the Minas Gerais State, Brazil, in the agricultural years 2012/13,2013/14 and 2015/16. The experimental plots consisted of three random samples within the arracacha observation units. Each sample consisted of five plants collected in sequence, highlighting and weighing commercial roots and transforming the portion of the production data for $\mathrm{tha}^{-1}$. Individual and joint variance analyzes were performed and, with the adjusted means the Scott-Knott grouping test was done. The bissegmented regression factors were analysed to obtain the stability and adaptability. The EH-56 clone stood out for its productive potential in almost all environments, superior to the other clones. The EH-56 clone stood out as the most suitable through the analysis of factors methodology, while BRS Rubia 41 and BRS Catarina 64 had specific adaptation to some environments and Amarela de Senador Amaral, variety that has been multiplied locally by farmers for over 15 years is little adapted. By bissegmented regression, no clone had ideal behavior. However, BRS Rubia 41 stands out for good adaptation in favorable environments. The analysis of factors associated to the bissegmented regression allows better accuracy in the response of arracacha clones to stability and adaptability.
\end{abstract}

Keywords: Arracacia xanthorrhiza, peruvian carrot, genotype $\mathrm{x}$ environment interaction, cultivars.

\section{RESUMO}

Adaptabilidade e estabilidade de produção comercial de mandioquinha-salsa no Sul de Minas Gerais

A mandioquinha-salsa representa uma ótima alternativa econômica para os horticultores no Brasil. Objetivou-se verificar a estabilidade e adaptabilidade de clones de mandioquinha-salsa pela metodologia da Análise de Fatores e Regressão Bissegmentada. Cinco clones, sendo três cultivares comerciais (Amarela de Senador Amaral, BRS Rubia 41 e BRS Catarina 64) e dois clones avançados (EH-48 e EH56), foram avaliados em 10 locais no Sul do estado de Minas Gerais nos anos agrícolas 2012/13, 2013/14 e 2015/16. As parcelas experimentais consistiram da retirada de três amostras aleatórias dentro das unidades de observação de mandioquinha-salsa. Cada amostra foi constituída de cinco plantas coletadas em sequência, destacando-se e obtendo-se a massa das raízes comerciais, transformando os dados de produção da parcela para $t$ ha $^{-1}$. Foram realizadas análises de variância individuais e conjunta dos experimentos e, com as médias ajustadas, realizou-se o teste de agrupamento de Scott-Knott e análises de fatores de regressão bissegmentada para o estudo da estabilidade e adaptabilidade. O clone EH-56 destacou-se pelo potencial produtivo sendo, em quase todos os ambientes, superior aos demais clones. O clone EH-56 se destacou como o mais adaptado pela metodologia de análise de fatores, enquanto BRS Rubia 41 e BRS Catarina 64 tiveram adaptação específica a alguns ambientes e, Amarela de Senador Amaral, variedade que vem sendo multiplicada localmente pelos agricultores há mais de 15 anos, pouco adaptada. Pela regressão bissegmentada, nenhum clone teve comportamento ideal. Contudo, BRS Rubia 41 destaca-se pela boa adaptação em ambientes favoráveis. A análise de fatores associada à regressão bissegmentada permite melhor acurácia na resposta dos clones de mandioquinha-salsa quanto à estabilidade e à adaptabilidade.

Palavras-chave: Arracacia xanthorrhiza, batata-baroa, interação genótipos x ambientes, cultivares.

\section{Received on November 22, 2016; accepted on October 13, 2017}

\begin{abstract}
A rracacha is one of the main vegetables grown in Brazil. It is estimated that approximately 16,000 hectares are planted annually, mainly in Paraná, Minas Gerais, Santa Catarina and Espírito Santo States. Paraná and Minas Gerais are the main producers, with an area of 7,600 and 6,000 ha, respectively (Zárate et al., 2009).
\end{abstract}

More than $90 \%$ of the planted area in Brazil is occupied with a cultivar named Amarela de Senador Amaral. The success of this cultivar is due, among other factors, to its high productivity and precocity, leading to the almost total replacement of other cultivars such as the ancient cultivar named Amarela Comum (Embrapa Hortaliças, 2015).
Facing the scarcity of cultivars available to the producers, it is possible to obtain new clones by means of sexual propagation and expression of progeny variability; being the arracacha tetraploid with high degree of heterozygosity (Hermann, 1997), the aim is to increase the alternatives of choice for the producers. However, 
the choice of new cultivars depends on the careful selection of clones that meet the requirements of the market presenting stability of production in different cultivation years and different climatic conditions, knowing that the environment interferes in the behavior of a genotype over the years (Mather \& Jinks, 1971).

To study the stability and adaptability many algorithms have been developed. Some depend on analysis of variance, others on regression or factor analyses, while the most recent ones use the analysis tools of restricted maximum likelihood/best linear unbiased prediction (REML/BLUP). The choice of either method depends on several factors such as number of environments evaluated, precision demanded and desired information (Cruz et al., 2012). However, it is a consensus that more reliable interpretations are only obtained when using at least two methods.

Among the analyzes of stability and adaptability used, the regression analysis proposed by Eberhart \& Russel (1966) is very frequently used. However, it presents some restrictions, since the environmental index is obtained by the average of the genotypes in each environment. Because of that the validity of the results is questionable when the number of environments or evaluated genotypes is small (Cruz et al., 2012).

Factor analysis is described by Johnson \& Wichern (1992). The principle is to establish a matrix of factorial loads. By this method it is possible to establish groups between correlated environments when factorial load values are positive and above 0.7 . Values between 0.5 and 0.7 do not allow any definition in the formation of groups of environments and, values smaller than 0.5 do not allow the formation of groups of environments. Stability analysis is performed by using a graph of easy visualization, in which parallel axes are plotted with the average of the scores, with formation of four quadrants. In the first quadrant are the genotypes of broad stability. In the second and fourth quadrants are genotypes with specific adaptation. In the second one are the genotypes adapted to favorable environments while in the fourth quadrant are the genotypes with good adaptation to unfavorable environments. The genotypes located in the third quadrant are the poorly adapted, low performance in any environment and therefore susceptible to discard.

The objective of this research was to evaluate the stability and adaptability of five arracacha genotypes in different locations in the southern State of Minas Gerais, through factor analysis and the regression method proposed by Eberhart \& Russel.

\section{MATERIAL AND METHODS}

The selected experimental areas for this study are representative of the main arracacha producing regions of Minas Gerais State (Santos, 1997) and present a Cwb climatic classification (humid temperate climate with dry winter and moderately hot summer). The competition of clones and cultivars was conducted in the following places: 1) Toledo-MG (1-Tol), Pereiras (2243'02' S, 46 23'50' W, $1131 \mathrm{~m}$ altitude) crop 2012/13;2) ToledoMG (2-Tol), Pereiras (22 $43^{\prime} 02^{\prime}$ 'S, $46^{\circ} 23^{\prime} 50^{\prime \prime} \mathrm{W}, 1131 \mathrm{~m}$ altitude) crop 2013/14; 3) Toledo-MG (3-Tol), Pereiras $\left(22^{\circ} 41^{\prime} 12^{\prime \prime} \mathrm{S}, 46^{\circ} 24^{\prime} 25^{\prime \prime} \mathrm{W}\right.$, $1171 \mathrm{~m}$ altitude) crop 2013/14; 4) Toledo-MG (4-Tol), Pereiras (2241'05' S, 46²4'19' 'W, $1204 \mathrm{~m}$ altitude) crop 2013/14; 5) Senador Amaral-MG (5-Sen), Campo Belo (2231'24" S, 46¹3'16"'W, $1450 \mathrm{~m}$ altitude) crop 2013/14; 6) Munhoz-MG (6-Mun), Correntinha (22 $39^{\prime} 07^{\prime}$ 'S, $46^{\circ} 18^{\prime} 46^{\prime \prime} \mathrm{W}, 1395 \mathrm{~m}$ altitude) 2015/16 crop; 7) Toledo-MG (7-Tol), Pereiras (2240'59" S, 46²4'06"'W, $1225 \mathrm{~m}$ altitude) 2015/16 crop; 8) Munhoz-MG (8-Mun), Correntinha (22 39'20'S, $46^{\circ} 19^{\prime} 06^{\prime}$ 'W, $1383 \mathrm{~m}$ altitude), crop 2015/16; 9) Bueno BrandãoMG (9-Bue), Cigano (22 $30^{\prime} 25^{\prime}$ 'S, $46^{\circ} 21^{\prime} 56^{\prime \prime} \mathrm{W}, 1269 \mathrm{~m}$ altitude) crop 2015/16; 10) Espirito Santo do DouradoMG (10-ESD) Ponte Alta (21 ${ }^{\circ} 50^{\prime} 03^{\prime}$ 'S, 46 59'54"'W, 1316 m altitude) 2015/16 crop. Thus, ten environments were added for the studies of adaptability and stability. In each environment five genotypes of arracacha were evaluated: Amarela de Senador Amaral, a intense yellow cultivar, uniform and cylindrical roots, vegetative cycle of 7 to 10 months and medium tolerance to the gall nematodes; BRS Rubia 41, roots with similar characteristics to Amarela de Amaral Senador, stands out for the high production of propagules; BRS Catarina 64, shows root pattern similar to Amarela de Senador Amaral, vegetative cycle a little longer, between 7 and 11 months, very vigorous plants, great and easy to handle seedlings; EH48 clone that shows the same pattern of roots and vegetative cycle as the Amarela de Senador Amaral, but with purple rings in the flesh of the roots and EH-56 whose roots are light yellow, rough skin, vegetative cycle of 6 to 8 months, very vigorous and sensible to heat.

The plots were installed using seedlings produced and selected by the grower, pre-sprout system and planted between March and May of each agricultural year. The experimental area consisted of a single plot with 300 to 1,000 plants. The space between planting furrows was $0.70 \mathrm{~m}$ and between plants was $0.30 \mathrm{~m}$. The fertilization of planting and coverage varied according to the management of each grower. All plots received weekly conventional sprinkler irrigation, in periods when rainfall was scarce. Weeds were controlled with linurom or cletodim herbicides, plus manual weeding. Other cultural dealings were those used by the growers in theirs commercial crops.

The experiments were collected near the day of the commercial harvest of the farmers, that is, between 11 or 12 months after planting. The experimental plots consisted of the removal of three random replicates inside the observation plots of arracacha. Each sample consisted of five plants collected in a row, counting and weighing the marketable roots, that is, roots of medium to large size (15 to 20 $\mathrm{cm}$ ), well formed, without smooth spots, which was transformed to $t$ ha $^{-1}$.

All analyzes were performed with Genes software (version 2009.7.0) (Cruz, 2013). The data were submitted to the assumptions of the analysis of variance for each environment. As 
no restriction on variance analysis occurred, the same were performed for each environment and then combined analysis. Then, the Scott-Knott (1974) clustering test was used to analyze stability and adaptability parameters by factor analysis methodologies (Murakami \& Cruz, 2004) and the regression analysis developed by Eberhart \& Russel (1966).

\section{RESULTS AND DISCUSSION}

Observing the significance of the means of clones, there were highly significant differences between genotypes for all environments evaluated except for the 1-Tol environment $(p>0.05)$ (Table 1). This fact demonstrates differences in the productive potential among the evaluated genotypes and corroborate the possibility of finding clones more productive than the cultivar traditionally cultivated in the region. The coefficients of variation that measure the degree of experimental accuracy ranged from 13.38 to $30.05 \%$ for the 5 -Sen and $4-\mathrm{Tol}$ environments, respectively. However, most of the coefficients were less than $24 \%$, it means that they may be considered adequate, especially in the case of a little studied crop such as arracacha.
The Scott-Knott means clustering test (Table 1) revealed superiority of the EH-48 and EH-56 clones for all evaluated environments comparatively with the commercial cultivars. Among the commercial cultivars, the productive potential of the cultivars BRS Rubia 41 and BRS Catarina 64 is notorious, compared to the cultivar widely cultivated in the region, Amarela de Senador Amaral.

Table 2 presents the results of the factor analysis for the five arracacha clones evaluated in the six environments. We verified that, after the rotation of the factorial loads, Factor 1 grouped the environments 1-Tol, 2-Tol, 3-Tol, 5-Sem, 6-Mun, 9-Bue and 10-ESD, and factor 2 grouped 4-Tol, 8-Mun and 7-Tol. The fact that two factors can explain the variability between the behavior of the clones in the ten environments indicates the small influence of the environments on the productive performance of the clones and suggests the possibility of reducing the number of environments without compromising the results of validation of the arracacha clones.

From the environmental index, it was possible to observe that the environments 1-Tol, 5-Sem, 6-Mun and 7-Tol presented themselves as unfavorable, and the other environments were favorable (Table 3). For example, the 1-Tol and 2-Tol environments represent the same location and the same season, but with different indexes, only depending on the harvest time.

In the analysis of factors, for a satisfactory explanation of the data, a minimum number of factors that explain at least $80 \%$ of the variability is necessary. It is possible to observe that the first factor explained $85.20 \%$ of the variability (Table 2). The second factor was considered only to allow the construction of the plot graph (Figure 1). The EH-56 clone presented wide stability to the evaluated environments since it was allocated in the quadrant I. BRS Rubia 41 and EH-48 clone were positioned in quadrant II in the graph, which means that these genotypes have good adaptability to favorable environments, namely, 2-Tol, 3-Tol, 4-Tol, 8-Mun, 9-Bue and 10-ESD.

The cultivar Amarela de Senador Amaral (ASA) was positioned in the III quadrant of the factor analysis, which indicated that it was not adapted in any of the tested environments.

BRS Catarina 64 presented stable performance in 1-Tol, 5-Sen, 6-Mun and 7-Tol, unfavorable environments, which is observed by its positioning in the IV quadrant.

Table 1. Productivity average $\left(\mathrm{t} \mathrm{ha}^{-1}\right)$, of five arracacha clones evaluated in different environments of the South of Minas Gerais State. Brasília, Embrapa Hortaliças, 2016.

\begin{tabular}{|c|c|c|c|c|c|c|c|c|c|c|c|c|c|}
\hline \multirow{3}{*}{$\begin{array}{l}\text { Environments } \\
1-\mathrm{Tol}\end{array}$} & \multicolumn{10}{|c|}{ Genotypes } & \multirow{3}{*}{$\frac{\text { QM }}{213.11^{*}}$} & \multirow{3}{*}{$\begin{array}{l}\text { CV } \\
(\%)\end{array}$} & \multirow{3}{*}{$\begin{array}{r}\text { Average } \\
24.10\end{array}$} \\
\hline & \multicolumn{2}{|c|}{$\begin{array}{c}\text { BRS } \\
\text { Rubia 41 }\end{array}$} & \multicolumn{2}{|c|}{ EH-48 } & \multicolumn{2}{|c|}{ EH-56 } & \multicolumn{2}{|c|}{$\begin{array}{c}\text { BRS } \\
\text { Catarina } 64\end{array}$} & \multicolumn{2}{|l|}{ ASA } & & & \\
\hline & 15.48 & $\mathrm{Bb}$ & 30.19 & $\mathrm{Bd}$ & 35.33 & $\mathrm{Ac}$ & 17.31 & $\mathrm{Bb}$ & 22.20 & $\mathrm{Bb}$ & & & \\
\hline 2-Tol & 45.07 & $\mathrm{Ca}$ & 82.58 & $\mathrm{Bb}$ & 114.65 & $\mathrm{Aa}$ & 51.43 & $\mathrm{Ca}$ & 20.53 & $\mathrm{Db}$ & $6638.18^{* *}$ & 15.16 & 62.85 \\
\hline 3-Tol & 24.29 & $\mathrm{Cb}$ & 62.54 & $\mathrm{Ab}$ & 85.71 & $\mathrm{Ab}$ & 44.76 & $\mathrm{Ba}$ & 37.94 & $\mathrm{Ba}$ & $2261.46^{* *}$ & 21.55 & 51.05 \\
\hline 4-Tol & 45.68 & $\mathrm{Ba}$ & 106.56 & $\mathrm{Aa}$ & 106.42 & $\mathrm{Aa}$ & 45.44 & $\mathrm{Ba}$ & 31.58 & $\mathrm{Ba}$ & $5291.94 * *$ & 30.05 & 67.14 \\
\hline 5-Sen & 10.65 & $\mathrm{Bb}$ & 21.39 & $\mathrm{Bd}$ & 32.25 & Ac & 17.68 & $\mathrm{Bb}$ & 9.33 & $\mathrm{Bb}$ & $257.59 * *$ & 13.38 & 18.26 \\
\hline 6-Mun & 19.28 & $\mathrm{Bb}$ & 29.22 & $\mathrm{Bd}$ & 35.91 & Ac & 22.71 & $\mathrm{Bb}$ & 13.30 & $\mathrm{Bb}$ & $30.65^{* *}$ & 21.02 & 24.08 \\
\hline 7-Tol & 40.39 & $\mathrm{Aa}$ & 51.58 & Ac & 47.62 & Ac & 30.79 & $\mathrm{Bb}$ & 26.64 & $\mathrm{Bb}$ & $99.24 * *$ & 15.77 & 39.40 \\
\hline 8-Mun & 32.50 & $\mathrm{Ba}$ & 73.64 & $\mathrm{Ab}$ & 57.81 & $\mathrm{Bc}$ & 33.11 & $\mathrm{Ba}$ & 33.96 & $\mathrm{Ba}$ & $47.54 * *$ & 14.27 & 46.20 \\
\hline 9-Bue & 38.82 & $\mathrm{Ba}$ & 68.73 & $\mathrm{Ab}$ & 81.78 & $\mathrm{Ab}$ & 46.93 & $\mathrm{Ba}$ & 33.96 & $\mathrm{Ba}$ & $252.84 * *$ & 20.49 & 54.04 \\
\hline 10-ESD & 23.68 & $\mathrm{Cb}$ & 40.93 & $\mathrm{Bc}$ & 112.71 & $\mathrm{Aa}$ & 28.50 & $\mathrm{Cb}$ & 20.46 & $\mathrm{Cb}$ & $447.73 * *$ & 27.45 & 45.26 \\
\hline Average & 29.58 & & 56.73 & & 71.02 & & 33.87 & & 24.99 & & & & \\
\hline
\end{tabular}

Means followed by the same capital letter in line or lowercase letter in column belong to the same group based on the Scott-Knott grouping test, $5 \%$ probability. 
Table 2. Summary of the Analysis Factors for five arracacha clones evaluated in six environments in the seasons 2012/13, 2013/14 and 2015/16 in the South Minas Gerais State. Brasília, Embrapa Hortaliças, 2016.

\begin{tabular}{|c|c|c|c|c|c|c|c|}
\hline \multicolumn{3}{|c|}{ Estimatives of auto-value } & \multirow{2}{*}{ Environment } & \multicolumn{2}{|c|}{ Factorial charges after rotation } & \multirow{2}{*}{$\operatorname{Com}^{1}$} & \multirow{2}{*}{$\mathbf{I A}^{/ 2}$} \\
\hline Root & (\%) Root & (\%) Acumulated & & Factor 1 & Factor 2 & & \\
\hline 8.52 & 85.20 & 85.20 & 1-Tol & 0.71 & 0.45 & 0.72 & -18.58 \\
\hline 0.82 & 8.24 & 93.44 & 2-Tol & 0.78 & 0.59 & 0.96 & 19.55 \\
\hline 0.52 & 5.17 & 98.61 & 3-Tol & 0.88 & 0.42 & 0.96 & 7.75 \\
\hline 0.14 & 1.39 & 100.00 & 4-Tol & 0.59 & 0.81 & 1.00 & 23.83 \\
\hline . & . & 100.00 & 5-Sen & 0.89 & 0.42 & 0.97 & -25.04 \\
\hline . & . & 100.00 & 6-Mun & 0.77 & 0.59 & 0.94 & -19.22 \\
\hline . & . & 100.00 & 7-Tol & 0.32 & 0.91 & 0.93 & -3.90 \\
\hline . & . & 100.00 & 8-Mun & 0.36 & 0.89 & 0.93 & 2.90 \\
\hline . & . & 100.00 & 9-Bue & 0.78 & 0.62 & 0.99 & 10.74 \\
\hline . & . & 100.00 & 10-ESD & 0.95 & 0.24 & 0.95 & 1.96 \\
\hline
\end{tabular}

${ }^{11}$ Communalities; ${ }^{12}$ Envirolmental Index.

Table 3. Estimates of stability and adaptability from the character mass of commercial roots with the methodology of Cruz et al. (1989) for five arracacha genotypes evaluated in six environments in the seasons 2012/13, 2013/14 and 2015/16 in the South Minas Gerais State. Brasília, Embrapa, 2016.

\begin{tabular}{lccccccc}
\hline \multirow{2}{*}{ Clone } & \multicolumn{2}{c}{ Means in the environments } & \multirow{2}{*}{$\boldsymbol{\beta}_{1 \mathrm{i}}$} & $\boldsymbol{\beta}_{1 \mathrm{i}}+\boldsymbol{\beta}_{2 \mathrm{i}}$ & $\hat{\sigma}_{g \mathrm{i}}^{2}$ & \multirow{2}{*}{$\mathbf{R}^{2}(\boldsymbol{\%})$} \\
\cline { 2 - 4 } & General & Unfav. & Fav. & & & & \\
\hline BRS Rubia 41 & 29.58 & 21.45 & 35.01 & $0.60^{* *}$ & $0.96^{\text {ns }}$ & $138.35^{++}$ & 77.53 \\
EH-48 & 56.74 & 33.10 & 72.50 & $1.42^{* *}$ & $2.10^{* *}$ & $265.73^{++}$ & 90.61 \\
EH-56 & 71.02 & 37.78 & 93.18 & $1.85^{* *}$ & $1.24^{* *}$ & $935.63^{++}$ & 78.08 \\
BRS Catarina 64 & 33.86 & 22.12 & 41.69 & $0.70^{* *}$ & $0.78^{* *}$ & $73.78^{++}$ & 87.97 \\
ASA & 25.30 & 18.64 & 29.74 & $0.44^{* *}$ & $-0.08^{* *}$ & $166.69^{++}$ & 51.16 \\
\hline
\end{tabular}

***Significantly different from 1 by the t-test, at $5 \%$ and $1 \%$ of probability, respectively; ++ Significantly different from 0 by the F-test, at $1 \%$ of probability; ${ }^{n}$ not significant; $\beta_{1 i}=$ general means of the cultivar $\mathrm{i} ; \beta_{2 \mathrm{i}}=$ linear coefficient of regression associated to unfavorable environments; $\beta_{1 \mathrm{i}}+\beta_{2 \mathrm{i}}=$ linear coefficient of regression associated to favorable environments; $\hat{\sigma}_{g \mathrm{i}}^{2}=$ variance of the regression deviates; $\mathrm{R}^{2}=$ determination coefficients.

Analyzing the obtained results, based on these criteria, it is important to emphasize that by the method of factor analysis the cultivar ASA, which is widely used by the farmers of the South of Minas Gerais, would not be selected on the locations studied but discarded.

In this study, the ten evaluated environments were grouped by the factor analysis. Environmental clustering by the factor analysis has also been used in several crops such as soybean, corn and carrot. In the case of soybean (Mendonça et al., 2007) and maize (Garbuglio et al., 2007), the methodology of the factor analysis allowed to group most of the studied environments. However, Carvalho et al. (2014), evaluating carrot genotypes in the main Brazilian producing regions, succeed to group less than $50 \%$ of the evaluated environments.
This is due to the evaluation coverage, since Carvalho et al. (2014) evaluated carrot genotypes in much more diverse and distant environments than in the present study as also Mendonça et al. (2007) and Garbuglio et al. (2007)

The analysis of stability and adaptability by the bissegmented regression method proposed by Cruz et al. (1989) is shown in Table 3.

None of the genotypes of arracacha presented as ideal, since this methodology recommends that the ideal cultivar has high average, that is, the general average of the cultivar $\left(\beta_{1 \mathrm{i}}\right)$ has to be significantly inferior to 1 , the coefficient of linear regression associated with favorable environments $\left(\beta_{1 \mathrm{i}}+\beta_{2 \mathrm{i}}\right)$ has to be greater than 1 and with significance and non-significant deviations. The difficulty of finding the ideal genotype is also mentioned in other publications such as Backes et al. (2005), Mendonça et al. (2007) and Carvalho et al. (2014). However, the EH-48 and EH-56 clones are the most promising because they present a high general mean, high response in favorable environments $\left(\beta_{1 \mathrm{i}}+\beta_{2 \mathrm{i}}>1\right)$, but with a low predictability due to the significance of the regression deviations $\left(\hat{\sigma}_{g i}^{2}\right)$. The ASA cultivar presented higher adaptability to unfavorable environments $\left(\beta_{2 \mathrm{i}}=\right.$ $0,44 * *)$, but with low predictability $\left(\hat{\sigma}_{g i}^{2}=166,69 * *\right)$ and nonresponsive in changing environments (Table 3 ). The cultivars BRS Catarina 64 and BRS Rubia 41 were adapted to unfavorable environments, but with low predictability and low response in changing environments. The accuracy of the estimation coefficients $\mathrm{R}^{2}$ of the 


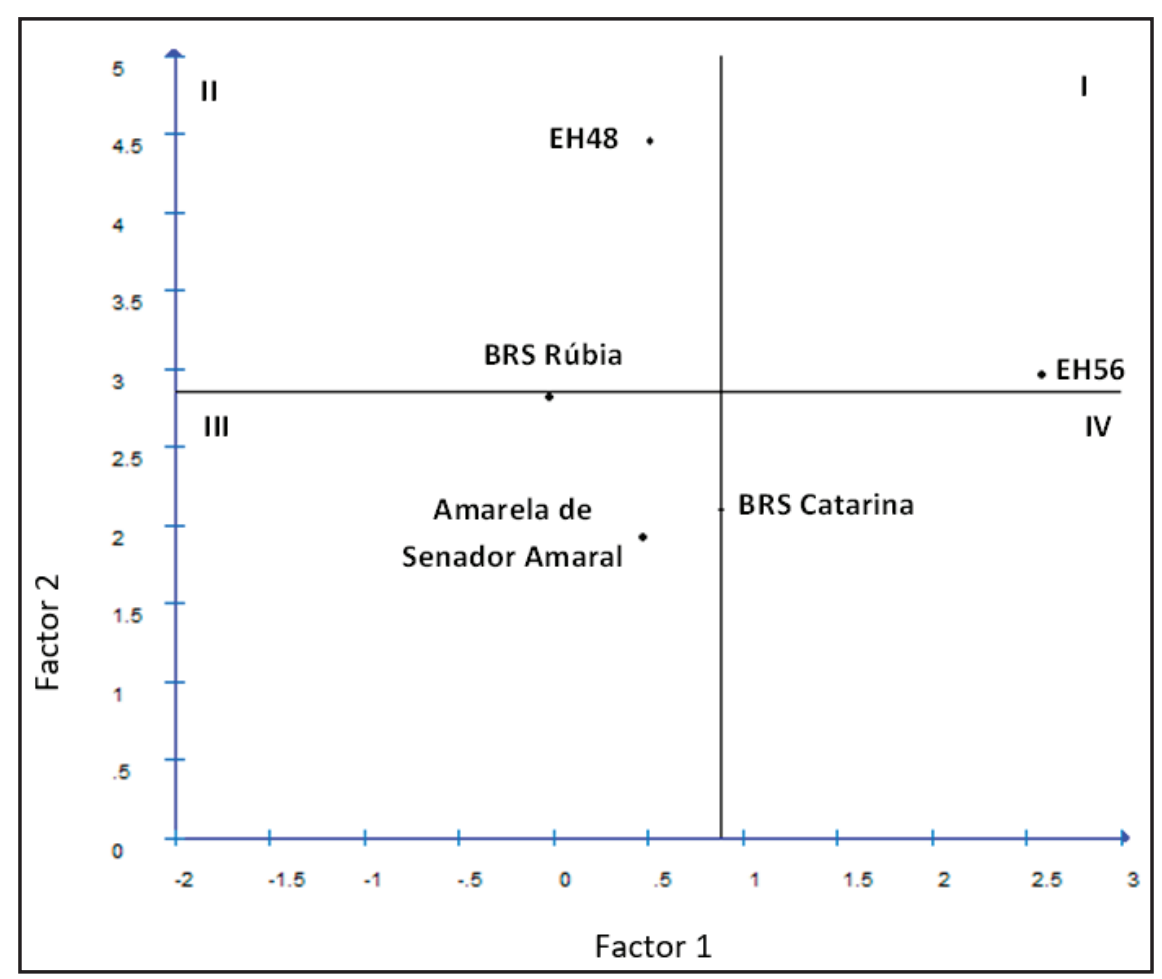

Figure 1. Scores plotation, considering the factors 1 and 2, related to the results obtained in the factor analisys of five aracacha clones evaluated in ten environments in the crop years 2012/13, 2013/14 and 2015/16 in the South Minas Gerais State. Brasília, Embrapa, 2016.

regression equations was greater than $77 \%$, with the exception of ASA that was $51.16 \%$.

There are no reports of researches about the stability and adaptability of arracacha in Brazil, aiming at the selection of more adapted clones. The few publications are from trials of evaluation of cultivars, but generally refer to one environment in specific regions. An important example of these studies was published by Madeira $\mathrm{et} \mathrm{al}$. (2002) in the evaluation of arracacha clones in Lavras-MG. The traditional cultivar ASA, at that time still incipient in relation to the planted area, already stood out for its precocity and capacity of response to the improvement of the environment, since at that time the predominant cultivar, Amarela Comum, was cultivated with low technological level. In Nova Friburgo-RJ, Portz et al. (2003) reported the productive potential of clone 92739 (ASA) compared to nine other clones from Embrapa Hortaliças.

The ASA cultivar studied in this research and that corresponds to more than $90 \%$ of the cultivated area all around Brazil arracacha regions, presented the worst stability and adaptability parameters. Certainly, the cultivar ASA has been cultivated for more than 15 years in the region without maintenance of any system of production of seedlings with high phytosanitary and physiological quality, which resulted in the accumulation of diseases and nonuniformity in the propagating material. This lack of care in the production of propagating material reflects a drop in productivity when compared to the first years of its introduction in the South of Minas Gerais, where there was a pattern of quality in propagules when implementing experiments and validation units at the time of its launch in 1998.

Considering crops poorly worked in breeding programs such as arracacha, the stability of production is often a very important factor, even being the environment favorable or not, and the choose of the cultivar should be taken into account.

There was a differentiated response of arracacha genotypes in relation to the studied environments. The factor analysis associated with the bissegmented regression allows better accuracy in the response of arracacha clones to stability and adaptability. By factor analysis, the EH-56 clone has shown to be the most adapted and stable considering the evaluated environments, BRS Rubia 41 and BRS Catarina 64 had specific adaptation to some environments and Amarela de Senador Amaral was not adapted. By the bissegmented regression, no clone had ideal behavior. However, EH-48 stands out by the good adaptation in favorable environments.

There are few literatures about the stability and adaptability of arracacha crop. The low availability of cultivars in the field, together with the difficulty of working with this species are factors responsible for the scarcity of publications. Amarela de Senador Amaral, at the time of its launching, stood out as a cultivar of great stability of production and adaptability compared to the traditional cultivar at that time, 'Amarela Comum'. Although EH-48 and EH-56 clones were very productive, non-commercial characteristics related to visual aspect prevented the release of these clones as cultivars. On the other hand, BRS Rubia 41 and BRS Catarina 64, were more promising than the aforementioned clones in relation to root quality. BRS Rubia 41 has shown to be an earlier clone and more adapted to regions with altitude close to $1,100 \mathrm{~m}$, while BRS Catarina 64, has shown to be a little later and with high production potential at altitudes close to $1,400 \mathrm{~m}$. This market positioning is important for producers to choose the best cultivar in relation to their needs and to explore the differences between the new cultivars of arracacha.

\section{ACKNOWLEDGMENTS}

The authors thank the producers Abel Miranda, Nelson Dantas, Tiago Marques, Edmar Melo, Célio Riciati and José Godoi for the availability of their production area to conduct the experiments.

\section{REFERENCES}

BACKES, RL; ELIAS, HT; HEMP, S; NICKNICH, W. 2005. Adaptabilidade e estabilidade de 
genótipos de feijoeiro no Estado de Santa Catarina. Acta Scientiarum 27: 309-314.

CARVALHO, ADF; SILVA, GO; PEREIRA, RB; PINHEIRO, JB. 2014. Análise de fatores e regressão bissegmentada no estudo da adaptabilidade e estabilidade de cenoura. Revista Ceres 61: 932-940.

CRUZ, CD. 2013. Genes: a software package for analysis in experimental statistics and quantitative genetics. Acta Scientiarum 35: 271-276.

CRUZ, CD; CARNEIRO, PCS. 2003. Modelos biométricos aplicados ao melhoramento genético. Viçosa: Editora UFV. 579p.

CRUZ, CD; REGAZZI, AJ; CARNEIRO, PC. 2012. Métodos biométricos aplicados ao melhoramento genético vol. 4. Viçosa: UFV. $414 \mathrm{p}$.

CRUZ, CD; TORRES, RD; VENCOVSKY, R. 1989. An alternative approach to the stability analysis proposed by Silva and Barreto. Revista Brasileira de Genética 12: 567-580.

EBERHART, SA; RUSSEL, WA. 1966. Stability parameters for comparing varieties. Crop Science 6: 36-40.

Embrapa Hortaliças. 2015. BRS Rúbia e BRS Catarina: Novas cultivares de mandioquinha- salsa ampliam as opções de cultivo da hortaliça. Hortaliças em Revista 16: 6-9.

GARBUGLIO, DD; GERAGE, AC; ARAÚJO, PM; FONSECA JUNIOR, NS; SHIOGA, OS. 2007. Análise de fatores e regressão bissegmentada em estudos de estratificação ambiental e adaptabilidade em milho. Pesquisa Agropecuária Brasileira 42: 183-191.

HERMANN, M. 1997. Arracacha (Arracacia xanthorrhiza Bancroft). In: Andean roots and tubers: Ahipa, arracacha, maca and yacon. Promoting the conservation and use of underutilized and neglected crops. 21. Gatersleben, Germany and Rome, Italy: IPGRI, p. 75-172.

JOHNSON, RA; WICHERN, DW. 1992. Applied multivariate statistical analysis. 3. ed. New Jersey: Prantice Hall. 642p.

MADEIRA, NR; SANTOS, FF; SOUZA, RJ. 2002. Desempenho de clones de mandioquinha-salsa (Arracacia xanthorrhiza Bancroft) na região de Lavras-MG. Ciência e Agrotecnologia 26: 711-718.

MATHER, K; JINKS, JL. 1971. Biometrical Genetics. 2a . ed. London: Chapman \& Hall Ltda., p.382.

MENDONÇA, O; CARPENTIERI-PÍPOLO, V;
GARBUGLIO, DD; FONSECA JUNIOR, NS. 2007. Análise de fatores e estratificação ambiental na avaliação da adaptabilidade e estabilidade em soja. Pesquisa Agropecuária Brasileira 42: 1567-1575.

MURAKAMI, DM; CRUZ, CD. 2004. Proposal of methodologies for environment stratification and analysis of genotype adaptability. Crop Breeding and Applied Biotechnology 4: 7-11.

PORTZ, A; MARTINS, CAC; LIMA, E; ZONTA, E. 2003. Avaliação de clones de mandioquinhasalsa (Arracacia xanthorrhyza Bancroft) na região de nova Friburgo-RJ. Revista Universidade Rural 23: 9-14.

SANTOS, FF. 1997. A cultura da mandioquinhasalsa no Brasil. Informe Agropecuário 19: 5-7.

SCOTT, AJ; KNOTT, MA. 1974. Cluster analysis method for grouping means in the analysis of variance. Biometrics 30: 507-512.

ZÁRATE, NAH; VIEIRA, MC; GRACIANO, JD; FIGUEIREDO, PG; BLANS, NB; CURIONI, BM. 2009. Produtividade de mandioquinhasalsa sob diferentes densidades de plantio e tamanho das mudas. Ciência e Agrotecnologia 33: 139-143. 